\title{
Показники редокс-стану крові у хворих на рак молочної залози: потенційні маркери прогнозу перебігу захворювання
}

\author{
${ }^{1}$ Інститут експериментальної патологї̈, онкології і радіобіологї̈ ім. Р.С. Кавецького НАН Украӥни, Киӥв \\ ${ }^{2}$ Національний медичний університет ім. О.О. Богомольця МОЗ Украӥни, Київ \\ ${ }^{3}$ Інститут фізики напівпровідників ім. В.С. Лашкарьова НАН Украӥни, Київ \\ Одержано 26.09.2019 \\ Прийнято до друку 10.10.2019 \\ DOI: $10.32471 /$ clinicaloncology.2663-466X.40.23055
}

\begin{abstract}
Вступ. У жінок постменопаузального віку рівень циркулюючого естрогену у сироватці крові та тканині грудної залози знижений, але частота розвитку раку грудної залози (РГЗ) залишається високою, що вказує на наявність інших чинників, що зумовлюють його виникнення. До останніх можна віднести здатність естрогену та його метаболітів порушувати рівновагу в редокс-стані органів та крові шляхом посилення генерування супероксидних радикалів, які виявляють як сигнальні, так і пошкоджуючі ефекти. Накопичилися дані щодо того, що окиснювальний метаболізм естрогену з утвореннями катехол-естроген-3,4-хінонів має потенціал ініціювати РГЗ. Мета. Дослідити рівень церулоплазміну (ЦП), трансферину (ТФ), NO-гемоглобіну (NO-Hb), метгемоглобіну (MetHb), “вільного" заліза, супероксид- і NO-генеруючої активності нейтрофілів та матриксних металопротеїназ-2 і -9 у крові хворих на РГЗ ІІ-ІІІ стадії з різним гормонорецепторним статусом пухлин. Об'єкт і методи. Досліджено кров хворих на РГЗ у репродуктивному та постменопаузальному віці. Рівень ЦП, ТФ, “вільного" заліза, геміхромів, МеtНb, NO-Hb та убісеміхінону досліджували методом електронного парамагнітного резонансу (ЕПР) у низькотемпературному режимі (77 К). Швидкість генерування супероксидних радикалів нейтрофілами визначали методом ЕПР при кімнатній температурі з використанням спінового уловлювача TEMPONE-H («Sigma»). NO-генеруючу активність нейтрофілів крові визначали методом ЕПР з використанням технології Spin Traps за температури 77 К (спіновий уловлювач - діетилдитіокарбамат). Рівень активних форм желатиназ у сироватці крові визначали методом зимографії у поліакриламідному гелі. Результати. У пацієнток репродуктивного та постменопаузального віку з естроген-рецептор (ER)(+)/прогестерон-рецептор (PR)(+) тa ER(-)/PR(-)-статусом пухлин рівень ЦП перевищував значення, характерні для донорів, а рівень ТФ був достовірно нижчим. Вміст у крові NO-Hb був найвищим у хворих на РГЗ у постменопаузальному віці з $\operatorname{ER}(-) / \mathrm{PR}(-)-$-статусом пухлин та прямо корелював з NO-генеруючою активністю нейтрофілів $(r=0,56 ; p<0,05)$. Активність матриксної металопротеїнази-9 у сироватці крові Xворих 3 ER(-)/PR(-)статусом пухлин у 3,3 раза достовірно перевищувала таку у хворих 3 ER(+)/PR(+). У крові 78\% хворих на PГЗ постменопаузального віку з $\operatorname{ER(-)/PR(-)~виявлено~підвищення~вмісту~метаболітів~естрогенів~-~хінонів~та~убісеміхінонів,~рівень~останніх~прямо~}$ корелював зі стадією пухлинного процесу $(r=0,58 ; p<0,05)$. Встановлено, що нейтрофіли в крові хворих репродуктивного віку $3 \mathrm{ER}(+) / \mathrm{PR}(+)$ та $\mathrm{ER}(-) / \mathrm{PR}(-)$ генерують супероксидні радикали зі швидкістю, яка $\epsilon$ відповідно у 9 та 18 разів вищою порівняно з донорами, а NO - більше ніж у 12 разів незалежно від гормонорецепторного статусу пухлин. Висновок. Виявлено порушення редокс-стану крові у хворих на РГЗ, зміни якого залежать від гормонорецепторного статусу пухлин, зокрема ER(+)/PR(+) та ER(-)/PR(-). Характерний для хворих на PГЗ редокс-стан крові формується підвищенням супероксид- та NO-генеруючої активності нейтрофілів, появою значних рівнів NO-Hb, MetHb, геміхромів, убісеміхінонів і активності желатиназ. Виявлено вплив визначених показників на перебіг захворювання та виживаність хворих на РГЗ.
\end{abstract}

Ключові слова: рак грудної залози, гормонорецепторний статус, редокс-стан крові, супероксидні радикали, оксид азоту.

\section{ВСТУП}

В усьому світі частота виникнення раку грудної залози (РГЗ) має тенденцію до підвищення, однією з причин чого є збільшення популяції осіб похилого віку, бо відомо, що ризик захворіти на РГЗ у віці $>65$ років у 150 разів перевищує такий у осіб віком $<30$ років. При цьому зниження показників смертності від РГЗ зазвичай вдається досягти за рахунок осіб молодого та середнього віку. Покращенням показників виживаності хворих на РГЗ ми зобов'язані більш ранній діагностиці та вдосконаленню методів лікування з використанням предиктивних та прогностичних чинників.

На сьогодні епідеміологічні та клінічні дані свідчать про те, що фактори, пов'язані з підвищеним рівнем естрогену протягом життя жінки, включаючи ранній початок менструації, пізню менопаузу, використання оральних контрацептивів, пізню першу вагітність та замісну гормональну терапію, підвищують ризик розвитку раку молочної залози серед жінок до і після менопаузи. Механізми канцерогенезу в молочній залозі спричинюються метаболізмом естрогенів з утворенням у ДНК апуринових ділянок та нерегульованим генеруванням радикальних форм кисню, які окисно пошкоджують макромолекули, зокрема ДНК. Накопичилися дані стосовно того, що окиснювальний метаболізм естро- генів з утвореннями катехол-естроген-3,4-хінонів має потенціал ініціації РГЗ. Надлишок радикальних форм кисню не тільки зумовлює генотоксичність, збільшуючи геномну нестабільність, але також стимулює прогресування канцерогенезу у грудних залозах шляхом індукування редоксзалежної сигналізації. Водночас під час менопаузи в організмі жінок підвищується рівень заліза, яке накопичується в результаті припинення крововтрат та деградації залізовмісних білків [1-5]. Порушення редокс-стану, депонування та регулювання рівня заліза, яке за фізіологічних умов забезпечує проліферацію та ріст клітин, є ключовим фактором виживання клітин у мікрооточенні як пухлин, так і метастазів, та може спричиняти прогресування РГЗ $[5,6]$.

Важливим етапом злоякісної трансформації є набуття здатності до інвазії та метастазування. Це досягається пухлинною клітиною шляхом поступової реорганізації цитоскелета, делокалізації молекул клітинної адгезії, зменшенням сили міжклітинних зв'язків та деградації екстрацелюлярного матриксу. Матриксні металопротеїнази (ММП)-2 та -9 (або, відповідно, желатинази А і В) - ферменти, які забезпечують протеоліз позаклітинного матриксу в процесах фізіологічної та патологічної реорганізації тканин організму, зокрема при онкологічних захворюваннях. Желатинази супроводжують метастазування 
на кожному етапі дисемінації пухлинних клітин, руйнуючи фізичні бар'єри на шляху дисемінуючих пухлинних клітин. Крім того, ці ферменти відіграють важливу регуляторну роль в пухлинному прогресуванні, забезпечуючи протеолітичний вплив на низку факторів росту, цитокінів, рецепторів та молекул, задіяних у пухлинному прогресуванні [7-9].

Метою роботи було дослідити рівень церулоплазміну (ЦП), трансферину (ТФ), NO-гемоглобіну (NO-Hb), метгемоглобіну (MetHb), супероксид- та NO-генеруючої активності нейтрофілів та ММП-2 і -9 у крові хворих на РГЗ II-III стадії з різним гормонорецепторним статусом пухлин.

\section{ОБ 'ЄКТ І МЕТОДИ ДОСЛІДЖЕННЯ}

Досліджено зразки крові 48 хворих на РГЗ ІІ-ІІІ стадії у репродуктивному віці (33,0 06,0 років) та 49 хворих на РГЗ у постменопаузальний період $(57,0 \pm 5,0$ років). Серед пацієнток репродуктивного віку у 24 відмічали естроген-рецептор $(\mathrm{ER})(+) /$ прогестерон-рецептор $(\mathrm{PR})(+)$-статус пухлин, у $17-\mathrm{ER}(-) / \mathrm{PR}(-)$. У групі постменопаузального віку було 27 та 22 жінки, відповідно, з ER(+)/PR(+) та ER(-)/PR(-)статусом РГЗ. У $100 \%$ випадків пухлини грудної залози за гістологічним типом були аденокарциномами. Хворі проходили лікування в Національному інституті раку Міністерства охорони здоров'я України. Випробування виконували відповідно до принципів проведення біомедичних досліджень, викладених у Гельсінській декларації Всесвітньої медичної асоціації. Пацієнти були поінформовані та дали згоду на використання клінічного матеріалу в дослідницьких цілях.

Рівень ЦП, ТФ, «вільного» заліза, геміхромів, MetHb, $\mathrm{NO}-\mathrm{Hb}$ та убісеміхінону досліджували методом електронного парамагнітного резонансу (ЕПР) в низькотемпературному режимі (77 K) [10]. Швидкість генерування супероксидних радикалів (СР) нейтрофілами визначали методом ЕПР при кімнатній температурі в парамагнітно чистому кварцовому д'юарі з використанням спінового уловлювача TEMPONE-H («Sigma»). NO-генеруючу активність нейтрофілів крові визначали методом ЕПР з використанням технології Spin Traps за температури 77 К. Як спіновий уловлювач використовували діетилдитіокарбамат («Sigma») [11]. Нейтрофіли крові виділяли відповідно до методики [12]. У якості контролю використовували визначені тими ж методиками показники в умовно здорових жінок $(\mathrm{n}=17)$ віком 35-63 роки. Спектри ЕПР при температурі рідкого азоту (77 K) реєстрували у парамагнітно чистому кварцовому д’юарі на комп'ютеризованому спектрометрі РЕ-1307 з резонатором $H_{011}$. Рівень досліджуваних показників представлено у відносних одиницях (відн. од.), порівняно із стандартом інтенсивності, у якості якого використовували спеціально орієнтований зразок монокристалу рубіну $\left(\mathrm{Al}_{2} \mathrm{O}_{3}\right)$ з низьким вмістом іонів $\mathrm{Cr}^{3+}$. Помилка методу інтегрування спектрів та діапазон відтворення спектрів одного зразка становить не більше 3\%. Рівень активних форм желатиназ у сироватці крові визначено методом зимографії у поліакриламідному гелі на основі SDS-електрофорезу білків [13]. Дані представлені у вигляді середніх значень зі стандартним відхиленням $(\mathrm{M} \pm \mathrm{SE})$. Виживаність хворих аналізували за методом Каплана - Мейєра, для парних порівнянь використовували log-rank критерій [14]. Статистичний аналіз проводили із застосуванням програмного пакету R. Різницю між показниками вважали достовірною при $\mathrm{p}<0,05$.

\section{РЕЗУЛЬТАТИ ТА ЇХ ОБГОВОРЕННЯ}

ЦП є білком гострої фази запалення і багатофункціональним ферментом, який проявляє активність амінооксидази, супероксиддисмутази та ферооксидази. Він каталізує окиснення $\mathrm{Fe}^{2+}$ до $\mathrm{Fe}^{3+}$, що важливо для навантаження апо-ТФ іонами заліза $[1,15]$. У крові людини методом ЕПР реєструють ЦП, що ідентифікується за інтенсивністю сигналу ЕПР з $g=2,05$, $2,209$ ( $\mathrm{A}=155-200$ Гс $)$, який має низькоінтенсивну компоненту $3 g=2,003$ і шириною пік-пік 1,27 мТ. Лінії ЕПР з $g$-факторами в діапазоні $g=2,00$ і $\Delta H p p=1,03-1,37$ мТ спостерігалися в спектрах ЕПР крові $\approx 78 \%$ хворих на РГЗ і мали вільнорадикальну природу. У пацієнток репродуктивного віку з $\mathrm{ER}(+) / \mathrm{PR}(+)-$ статусом пухлин виявлено, що рівень ЦП майже вдвічі перевищував значення донорів $(0,78 \pm 0,08$ відн. од.) та становив $1,50 \pm 0,13$ відн. од., тоді як у хворих з $\mathrm{ER}(-) / \mathrm{PR}(-)$-статусом цей показник становив $1,06 \pm 0,08$ відн. од. $(\mathrm{p}<0,05)$ (рис. 1$)$.

$\mathrm{y}$ жінок в постменопаузальному віці з $\mathrm{ER}(+) / \mathrm{PR}(+)-$ статусом РГЗ рівень ЦП перевищував контрольні значення і становив $1,21 \pm 0,09$ відн. од. $(\mathrm{p}<0,05)$, у пацієнток $3 \mathrm{ER}(-) / \mathrm{PR}(-)$-статусом цей показник визначався на рівні 0,67 $\pm 0,09$ відн. од. та достовірно не відрізнявся від значень у донорів (p>0,05). У пацієнток з $\mathrm{ER}(+) / \mathrm{PR}(+)$-статусом пухлини в репродуктивному та постменопаузальному віці рівень ЦП значно вищий порівняно з хворими з $\mathrm{ER}(-) / \mathrm{PR}(-)-$ статусом РГЗ, тож посилення антиоксидантного захисту в крові цих пацієнток може сприяти позитивній відповіді на хіміотерапію.

ТФ в організмі людини виконує різні функції, основна з яких полягає в транспортуванні заліза в клітини, що забезпечує процеси росту, проліферації, диференціювання, апоптозу клітин та є складовою системи захисту організму від накопичення «вільного» заліза $[13,16]$. У хворих на РГЗ у репродуктивному віці з $\mathrm{ER}(+) / \mathrm{PR}(+)$ та $\mathrm{ER}(-) / \mathrm{PR}(-)$-статусом виявлено рівень ТФ $0,34 \pm 0,08$ та $0,47 \pm 0,07$ відн. од. відповідно, що достовірно нижче порівняно з контролем $-0,81 \pm 0,10$ відн. од. $(\mathrm{p}<0,05)$ (див. рис. 1). Рівень ТФ у крові пацієнток постменопаузального віку з $\mathrm{ER}(+) / \mathrm{PR}(+)$ та $\mathrm{ER}(-) / \mathrm{PR}(-)$-статусом становив $0,71 \pm 0,10$ та $0,98 \pm 0,15$ відн. од. відповідно. МetHb, феридезоксигемоглобін у високоспіновому стані, утворюється внаслідок окисно-індукованого гемолізу та окиснення $\mathrm{Fe}^{2+}$ в гемоглобіні (Hb) СР. Рівень МetНb в крові донорів не перевищує 1-1,5\% $(0,08 \pm 0,02$ відн. од.) від загального рівня Нb. У крові хворих на РГЗ постменопаузального віку з $\mathrm{ER}(-) / \mathrm{PR}(-)$-статусом цей показник підвищується до $0,45 \pm 0,07$ відн. од. $(p<0,05)$ за рахунок окиснення та накопичення «вільного» заліза при припиненні менструації (зниження втрат заліза), що призводить до перенавантаження організму цим елементом $[1,3]$. Це також може відбуватися за рахунок декомпартменталізації іонів заліза внаслідок активації окисних пошкоджень ліпідів, білків, відновного перетворення ТФ на апо-ТФ, а також «виходу» депонованого заліза із феритину [17-19]. Але МetHb може піддаватися подальшій деструкції з утворенням різних форм геміхромів - низькоспінових форм МеtНb, тому його рівень у крові цих хворих може змінюватися в бік зниження з накопиченням геміхромів. Підвищення цих показників може бути важливим етіологічним фактором у розвитку та прогресуванні РГЗ, оскільки вони є каталізаторами реакцій аутоокиснення та подальшого підвищення генерування СР.

У крові $78 \%$ хворих на РГЗ постменопаузального віку з ER(-)/PR(-)-статусом пухлин виявлено також сигнали ЕПР, які характеризують $\operatorname{MetHb}(g=6,0)$, «вільне» залізо $(g=2,20-2,40)$ та геміхроми $(g=2,62)$, метаболіти естрогенів - хінони та убісе-

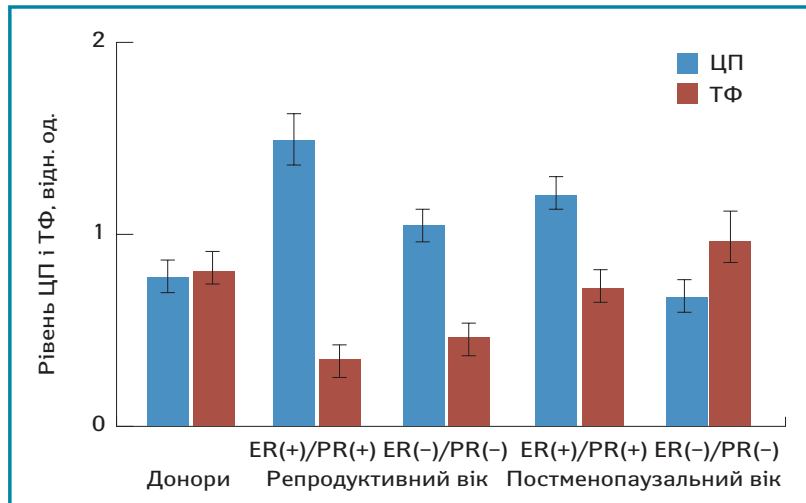

Рис. 1. Рівень ЦП та ТФ у крові хворих на РГЗ залежно від віку та гормонорецепторного статусу пухлин 
міхінони $(g=2,00)$, рівень вмісту останніх підвищувався та прямо корелював зі стадією пухлинного процесу $(\mathrm{r}=0,58 ; \mathrm{p}<0,05)$.

Оксид азоту (NO), у разі підвищення його рівня в крові, дифундує в еритроцити та реагує з $\mathrm{Hb}[20,21]$. Відбувається окисно-відновна реакція, за якої NO утворює стабільний комплекс з $\mathrm{Hb}$ (NO-Hb), а двохвалентне залізо окиснюється до трьохвалентного. У пацієнток репродуктивного віку з $\mathrm{ER}(-) / \mathrm{PR}(-)$-статусом РГЗ рівень $\mathrm{NO}-\mathrm{Hb}$ (який має спектральні характеристики $g_{1}=2,07, g_{2}=1,98$ та $g_{\text {сер }}=2,01$ та триплетне розщеплення) становив $0,58 \pm 0,13$ відн. од. та достовірно перевищував такий при $\mathrm{ER}(+) / \mathrm{PR}(+)$-статусі пухлин $0,31 \pm 0,07$ відн. од. $(\mathrm{p}<0,05)$. У хворих у постменопаузальному віці з $\mathrm{ER}(-) / \mathrm{PR}(-)$ пухлинами рівень цього показника становив 2,45 $\pm 0,27$ відн. од., що у 1,5 раза вище порівняно з хворими, гормонорецепторний статус пухлин який був $\mathrm{ER}(+) / \mathrm{PR}(+)-$ $1,61 \pm 0,22$ ( $<0,05)$ (рис. 2). Слід зазначити, що цей показник у крові донорів не визначається. Найвищий рівень $\mathrm{NO}-\mathrm{Hb}$ (до 4,5 $\pm 0,87$ відн. од.) було визначено у хворих на РГЗ у постменопаузальному віці з $\mathrm{ER}(-) / \mathrm{PR}(-)$-статусом $(\mathrm{n}=6)$, який прямо корелював з рівнем NO-генеруючої активності нейтрофілів $(\mathrm{r}=0,56 ; \mathrm{p}<0,05)$.

Рівень супероксид-генеруючої активності нейтрофілів у хворих на РГЗ у репродуктивному віці з $\mathrm{ER}(+) / \mathrm{PR}(+)$ та $\mathrm{ER}(-) / \mathrm{PR}(-)-$-татусом пухлин (рис. 3) становив $1,69 \pm 0,11$ та 3,49 $\pm 0,27$ нМоль $/ 10^{5}$ клітин 'хв, що у 9 та 18 разів достовірно вище, ніж у донорів $\left(0,19 \pm 0,08\right.$ нМоль $/ 10^{5}$ клітин·хв). У пацієнток постменопаузального віку з $\mathrm{ER}(+) / \mathrm{PR}(+)$-статусом цей показник реєструвався на рівні 4,63 $\pm 0,39$ нМоль $/ 10^{5}$ клітин·хв, а з $\mathrm{ER}(-) / \mathrm{PR}(-)-5,04 \pm 0,42$ нМоль $/ 10^{5}$ клітин·хв, що вище порівняно 3 хворими репродуктивного віку та донорами $(\mathrm{p}<0,05)$. $\mathrm{NO}$-генеруюча активність нейтрофілів крові (див. рис. 3) у донорів становила $0,23 \pm 0,03$ нМоль $/ 10^{5}$ клітин. У хворих на РГЗ репродуктивного віку з $\mathrm{ER}(+) / \mathrm{PR}(+)$ та $\mathrm{ER}(-) / \mathrm{PR}(-)$-статусом пухлин цей показник становив 2,75 $\pm 0,24$ та $2,93 \pm 0,30$ нМоль $/ 10^{5}$ клітин $(\mathrm{p}<0,05)$ відповідно. У пацієнток постменопаузального віку з $\mathrm{ER}(+) / \mathrm{PR}(+)$-статусом рівень NO становив $3,26 \pm 0,29$ нМоль $/ 10^{5}$ клітин, з $\mathrm{ER}(-) / \mathrm{PR}(-)$-статусом $4,17 \pm 0,35$ нМоль $/ 10^{5}$ клітин. У крові хворих на РГЗ підвищення рівнів оксиду азоту є наслідком посилення синтезу iNOS-нейтрофілів, а у разі надлишкових рівнів генерування він втрачає свої захисні функції та виявляє вазодепресивну і цитотоксичну дію.

Нами визначено, що активність ММП-2 в сироватці крові хворих на РГЗ постменопаузального віку з $\mathrm{ER}(-) / \mathrm{PR}(-)-$ статусом пухлин у 3-6 разів перевищує таку в інших групах хворих. Активність ММП-9 у хворих з ER(-)/PR(-)-статусом пухлин як репродуктивного, так і постменопаузального віку перевищує таку при $\mathrm{ER}(+) / \mathrm{PR}(+)$ гормонорецепторному статусі відповідно у 3 та 2,7 раза (p<0,05) (рис. 4). Отримані дані свідчать про асоціацію високих рівнів ММП-9 з гормонорецепторним статусом пухлини у хворих на РГЗ [22-26]. Такий зв'язок може

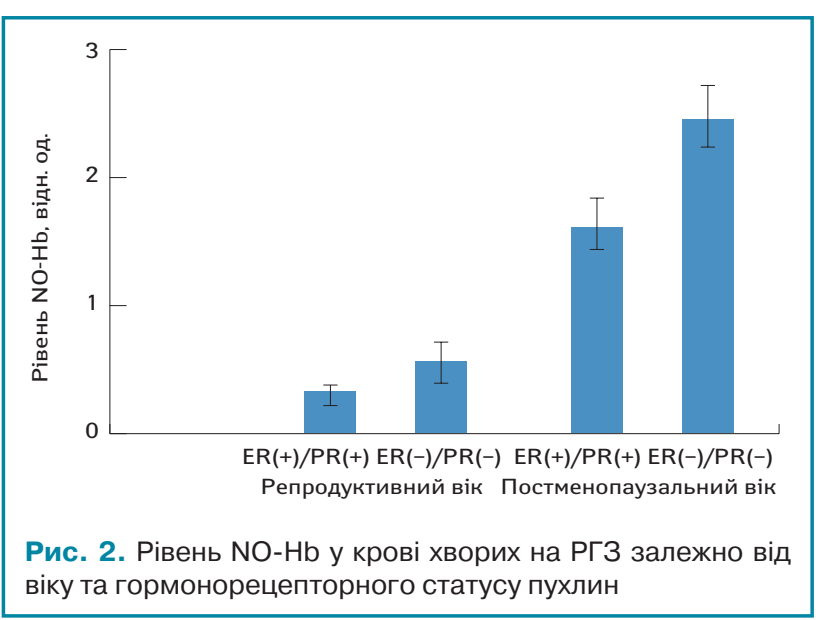

бути результатом гормонозалежного контролю активності желатиназ, який, зважаючи на вищенаведені дані щодо генерування СР, може реалізовуватися шляхом редокс-активації цих ферментів [27-29]. 3 іншого боку, можливо, навпаки, відбувається вплив желатиназ на гормонорецепторний статус пухлин. В останні роки багатьма дослідженнями доведено, що участь ММП в пухлинному прогресуванні значно ширша, ніж протеолітичний супровід дисемінуючих пухлинних клітин. Зокрема, вони чинять протеолітичний вплив на молекули і рецептори при пухлинному прогресуванні і таким чином виступають як регуляторні фактори. При цьому може відбуватися протеолітичне відщеплення та вивільнення низки факторів росту, цитокінів, рецепторів та молекул, задіяних у пухлинному прогресуванні, протеолітичне ремодулювання деяких рецепторів або їх повне руйнування. Можливо, такий механізм лежить в основі взаємозв'язку між рівнями ММП, естрогенів та їх рецепторів.

Проаналізовано 5-річну загальну виживаність (3В) хворих на РГЗ залежно від рівня вищезазначених показників. Статистично достовірну різницю виявлено при аналізі ЗВ залежно від рівня $\mathrm{NO}-\mathrm{Hb}$ в крові (рис. 5). У хворих репродуктивного віку (А), у яких рівень NO-Нb був вище медіани (>0,38 відн. од.), 5-річна 3В становила 43\%. У хворих постменопаузального віку (Б) з рівнем NO-Нb вище медіани (>1,94 відн. од.) 5-річна 3В становила $34 \%$.

При поєднанні високих рівнів МetHb, геміхромів з локально високими концентраціями естрогену в молочних залозах, активація генерування СР та активація ММП може каталізувати циклічне окиснення з деградацією мікрооточення клітин. Метаболіти естрогенів хінони та убісеміхінони, які є джерелом генерування СР, можуть спричиняти порушення редокс-стану крові. Естрогени ініціюють генерування СР, впливаючи на активність мітохондрій, за рахунок того, що фенольна гідроксильна група

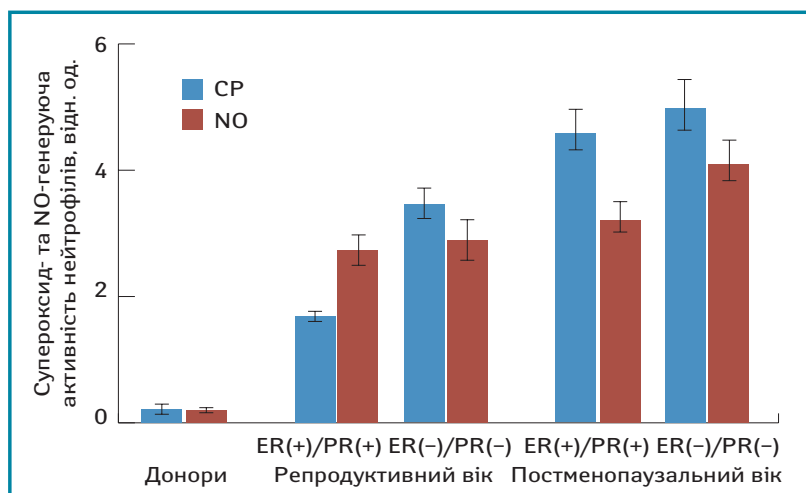

Рис. 3. Рівень супероксид- та NO-генеруючої активності нейтрофілів у хворих на РГЗ залежно від віку та гормонорецепторного статусу пухлин

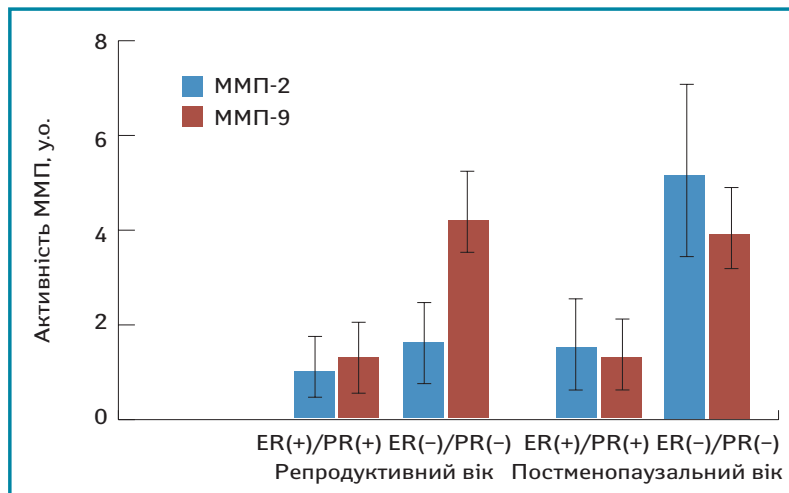

Рис. 4. Активність желатиназ у сироватці крові хворих на РГЗ залежно від віку та гормонорецепторного статусу пухлин 

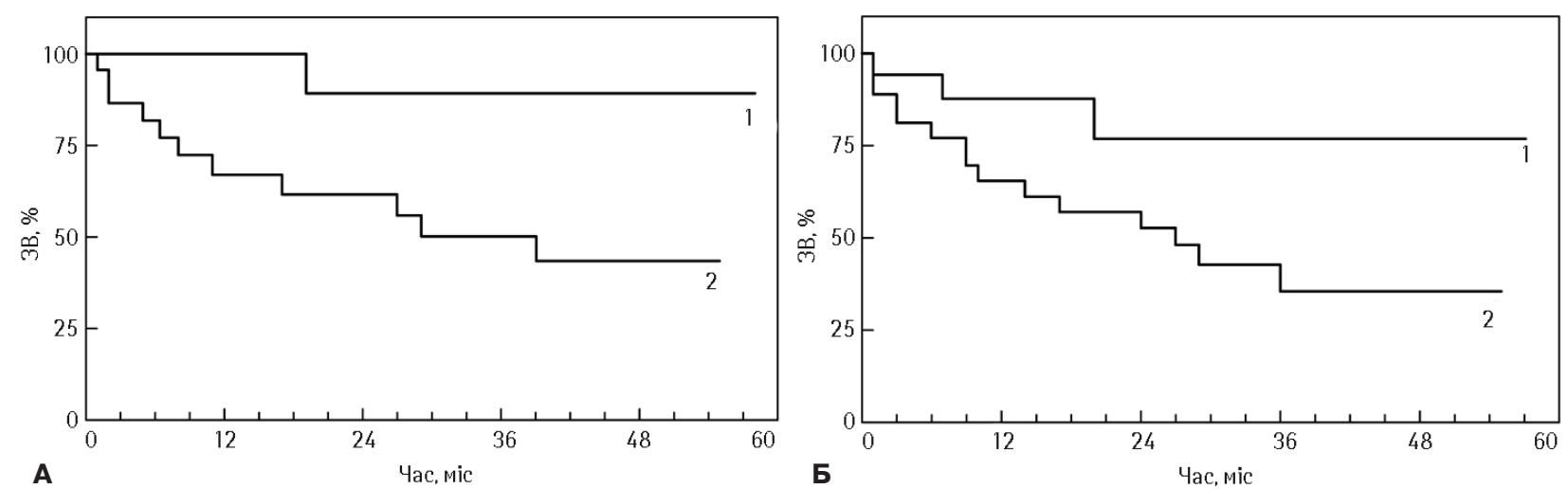

Рис. 5. ЗВ хворих на РГЗ І-ІІІ стадій репродуктивного (А) та постменопаузального (Б) віку залежно від рівня NO-Нb в крові. А: $1-<0,38$ відн. од. ( $n=18)$, медіана виживаності (МВ) не досягнута, $2->0,38$ відн. од. $(n=22)$, МВ становить 39 міс; $\chi^{2}=5,6$; p=0,02; Б: $1-<1,94$ відн. од. ( $n=17)$, МВ не досягнута, $2->1,94$ відн. од. $(n=25)$, МВ становить 27 міс; $\chi^{2}=3,6 ; p=0,05$

у положенні $\mathrm{C}_{3}$ гормону може окиснюватися, акцептуючи електрон, або втрачати протон і діяти як прооксидант. Крім того, естрогени можуть метаболізуватись до катехолів, які, окиснюючись до хінонів та убісеміхінонів у редокс-циклі, генерують СР. При підвищенні дози естрогенів метаболічні реакції, які є нешкідливими при низьких рівнях, можуть викликати окиснення естрогенів до відповідних хінонів та посилювати генерування СР в окиснювальному циклі естрогенів, діетилстилбестролу та хінонів. Активність ферментів, що підтримують циклічне окиснення естрогенів та генерування СР, корелює 3 ініціацією розвитку пухлин у молочних залозах $[1,2,4]$. За допомогою СР активуються мітогенактивований протеїнкіназний (МАР-кіназний), АР-1 і NFвідповідають за транскрипцію генів, що беруть участь у процесі росту і трансформації клітин. Отже, накопичення СР, NO, NO$\mathrm{Hb}, \mathrm{MetHb}$, геміхромів, убісеміхінонів в організмі жінок у період постменопаузи, а також застосування гормонозамісної терапії може спричиняти повторний (підсилений і більш тривалий) окиснювальний циклінг, що робить їх схильними до розвитку РГЗ та його прогресування [1-7].

\section{висновок}

Редокс-стан крові хворих на РГЗ змінюється залежно від гормонорецепторного статусу пухлин та віку пацієнток. Характерний для хворих на РГЗ редокс-стан крові формується зростанням супероксид- та NO-генеруючої активності нейтрофілів, появою значних рівнів $\mathrm{NO}-\mathrm{Hb}$, MetHb, геміхромів, убісеміхінонів і активності желатиназ. Виявлено вплив рівнів NO-Hb на виживаність хворих на РГЗ.

\section{СПИСОК ВИКОРИСТАНОÏ ЛІТЕРАТУРИ}

1. Fussell, K. C., Udasin, R. G., Smith, P. J., Gallo, M. A., \& Laskin, J. D. (2011). Catechol metabolites of endogenous estrogens induce redox cycling and generate reactive oxygen species in breast epithelial cells. Carcinogenesis, 32(8), 1285-1293. doi: 10.1093/carcin/bgr109.

2. Burlaka, A. P., \& Sidorik, E. P. (2014). Redox-dependent signal molecules in mechanisms of tumor process. Kyiv: Naukova dumka, 255 p. (in Ukrainian). ISBN 966-00-0463-X

3. Senkus, E., Kyriakides, S., Penault-Llorca, F., Poortmans, P., Thompson, A., Zackrisson, S., \& Cardoso, F. (2013). Primary breast cancer: ESMO Clinical Practice Guidelines for diagnosis, treatment and follow-up. Annals of Oncology, 24(Suppl 6) vi7-vi23. doi: 10.1093/annonc/mdt284.

4. Johar, R., Sharma, R., Kaur, A., \& Mukherjee, T. K. (2016). Role of reactive oxygen species in estrogen dependant breast cancer complication. Anticancer Agents Med Chem, 16(2), 190-199. doi: 10.2174/1871520615666150518092315.

5. Huang, X. (2008). Does iron have a role in breast cancer? Lancet Oncol, 9(8), 803-807. doi: 10.1016/S1470-2045(08)70200-6.

6. Torti, S. V., \& Torti, F. M. (2013). Cellular iron metabolism in prognosis and therapy of breast cancer. Crit Rev Oncog, 18(5), 435-448. doi: 10.1615/CritRevOncog.2013007784.

7. Burlaka, A. P., Ganusevich, I.I ., \& VovkA. V. (2017). Superroxide radicals: initiation of metastases in patients with breast cancer. Oncology, 19(3), 180-184. (in Ukrainian). Retrieved from oncology.kiev.ua/wp-content/themes/umj/pdf/19_3/180.pdf.

8. Song, N., Sung, H., Choi, J. Y., Han, S., Jeon, S., Song, M., Lee, Y., ... Kang, D. (2012). Preoperative serum levels of matrix metalloproteinase-2 (MMP-2) and survival of breast cancer among Korean women. Cancer Epidemiol Biomarkers Prev, 21(8), 1371-1380. doi: 10.1158/1055-9965.EPI-12-0293.
9. Ganusevich, I. I., Mamontova, L. A., Merentsev, S. P., \& Osinsky, S. P. (2015). Serum gelatinases as markers for monitoring of the clinical course of gastric cancer. Oncology, 17(2), 85-89. (in Ukrainian). Retrieved from oncology.kiev.ua/wp-content/themes/umj/pdf/17_2/85.pdf.

10. Burlaka, A. P., Gafurov, M. R., Iskhakova, K. B., Lukin, S. M., Rodionov, A. A., Sidorik, E. P., \& Vovk, A. V. (2016). Electron paramagnetic resonance in the experimental oncology: implementation examples of the conventional approaches. BioNanoScience, 6(4), 431-436. doi: 10.1007/s12668-016-0238-5.

11. Burlaka, A. P., Ganusevich, I. I., Golotiuk, V. V., Vovk, A. V., \& Lukin, S. M. (2016). Superoxide- and NO-dependent mechanisms of antitumor and antimetastatic effect of L-arginine hydrochloride and coenzyme Q10. Exp Oncol, 38(1), 31-35. Retrieved from exp-oncology.com.ua/wp/wp-content/uploads/2016/03/2252.pdf.

12. Kovalchuk, L. V., Ignatieva, G. A., \& Gankovska, L. V. (2010). Immunology. Moscow: GEOTAR-Media, 176 p. (in Russian).

13. Burlaka, A. P., Ganusevich, I. I., Gafurov, M. R., Lukin, S. M., \& Sidorik, Ye. P. (2013). Electron paramagnetic resonance study of tumor affected bone marrow. Cancer Microenvironment, 6(3), 273-276. doi: 10.1007/s12307-013-0137-z.

14. Kaplan, E. L., \& Meier, P. (1958). Nonparametric estimation from incomplete observations. J Amer Stat Ass, 53, 457-481. doi: 10.2307/2281868.

15. Kutsenko, L. O., \& Kaidashev I. P. (2011). The place of ceruloplasmin among the acute phase proteins as a marker of systemic inflammation. Lab diagnostics, 3(57), 59-68 (in Russian). Retrieved from irbis-nbuv.gov.ua /cgibin /irbis nbuv/cgiirbis 64.exe? C21COM=2\&I21DBN=UJRN\&P21DBN=UJRN\&IMAGE FILE DOWNLOAD=1\&Image file name=PDF/labdiag_2011_3 11.pdf.

16. Gkouvatsos, K., Papanikolaou, G., \& Pantopoulos, K. (2012). Regulation of iron transport and the role of transferrin. Biochim Biophys Acta, 1820(3), 188-202. doi: 10.1016/j.bbagen.2011.10.013.

17. Burlaka, A. P., Holotyuk, V. V., Vovk, A. V., Lukin, S. M., \& Sydoryk, Y. P. (2015). Blood redox state and survival in patients with rectal cancer. Medical and Clinical Chemistry, 17(4), 22-28. (in Ukrainian). doi: 10.11603/mcch.2410-681X.2015.v17.i4.5679.

18. Akhateeb, A. A., Han, B., \& Connor, J. R. (2013). Ferritin stimulates breast cancer cells through an iron-independent mechanism and is localized within tumor-associated macrophages. Breast Cancer Res Treat, 137(3), 733-744. doi: 10.1007/s10549-012-2405-x.

19. Wang, W., Knovich, M. A., Coffman, L. G., Torti, F. M., \& Torti, S. V. (2010). Serum ferritin: past, present and future. Biochim Biophys Acta, 1800(8), 760-769. doi: 10.1016/j.bbagen.2010.03.011.

20. Burke, A. J., Sullivan, F. J., Giles, F. J., \& Glynn, S. A. (2013). The yin and yang of nitric oxide in cancer progression. Carcinogenesis, 34(3), 503-512. doi: 10.1093/carcin/bgt034.

21. Dudok, K., Kaniuka, O., Fedorovych, A., Burda, V., \& Sybirna, N. (2016). Nodependent changing of the ligand form of hemoglobin in peripheral blood of people. Visnyk of the Lviv University (Series Biology), 73, 130-136. (in Ukrainian). Retrieved from prima.Inu.edu.ua/faculty/biologh/wis/73/2/32/32.pdf

22. Burlaka, A. P., Golotiuk, V. V., Vovk, A. V., Lukin, S. M., \& Sidorik, Ye. P. (2015). Influence of neutrophils $\mathrm{O}_{2}{ }^{-}$- and NO-generating activity on the effectiveness of neoadjuvant radiotherapy in patients with rectal cancer. Oncology, 17(4), 253-257. (in Ukrainian). Retrieved from oncology.kiev.ua/wp-content/themes/umj/pdf/17_4/253.pdf.

23. Pietraforte, D., Vona, R., Marchesi, A., de Jacobis, I. T., Villani, A., Del Principe, D., \& Straface, E. (2014). Redox control of platelet functions in physiology and pathophysiology. Antioxid Redox Signal, 21(1), 177-193. doi: 10.1089/ars.2013.5532.

24. Vizoso, F. J., González, L. O., Corte, M. D., Rodríguez, J. C., Vázquez, J., Lamelas, M. L., ... García-Muñiz, J. L. (2007). Study of matrix metalloproteinases and their inhibitors in breast cancer. British Journal of Cancer, 96(6), 903-911. doi: 10.1038/sj.bjc.6603666.

25. Mehner, C., Hockla, A., Miller, E., Ran, S., Radisky, D. C., \& Radisky, E. S. (2014). Tumor cell-produced matrix metalloproteinase 9 (MMP-9) drives malignant progression and metastasis of basal-like triple negative breast cancer. Oncotarget, 5(9), 2736-2749. doi: 10.18632/oncotarget. 1932

26. McGowan, P. M., \& Duffy, M. J. (2008). Matrix metalloproteinase expression and outcome in patients with breast cancer: analysis of a published database. Annals of Oncology, 19(9), 1566-1572. doi: 10.1093/annonc/mdn180.

27. Sag, C. M., Santos, C. X. C., \& Shah, A. M. (2014). Redox regulation of cardiac hypertrophy. J Mol Cell Cardiol, 73, 103-111. doi: 10.1016/j.yjmcc.2014.02.002.

28. Mikhed, Y., Görlach, A., Knaus, U. G., \& Daiber, A. (2015). Redox regulation of genome stability by effects on gene expression, epigenetic pathways and DNA damage/repair. Redox Biol, 5, 275-289. doi: 10.1016/j.redox.2015.05.008.

29. Okoh, V., Deoraj, A., \& Roy, D. (2011). Estrogen-induced reactive oxygen species-mediated signalings contribute to breast cancer. Biochim Biophys Acta, 1815(1), 115-133. doi: 10.1016/j.bbcan.2010.10.005. 
Показатели редокс-состояния крови у больных раком грудной железы: потенциальные маркеры прогноза течения заболевания

А.П. Бурлака ${ }^{1}$, А.И. Сидориук², И.Н. Мотузюк², С.В. Вирко В.А. Чернобайз , И.И. Ганусевич ${ }^{1}$

'Институт экспериментальной патологии, онкологии и радиобиологии им. Р.Е. Кавецкого НАН Украины, Киев ${ }^{2}$ Национальный медицинский университет им. А.А. Богомольца МЗ Украины, Киев ${ }^{3}$ Институт физики полупроводников им. В.Е. Лашкарева НАН Украины, Киев

Резюме. Введение. У женшин постменопаузального возраста уровень циркулирующего эстрогена в сыворотке крови и ткани грудной железы снижен, но частота развития рака грудной железы (РГЖ) остается высокой, что указывает на наличие других факторов, обусловливающих его возникновение. К последним можно отнести способность эстрогена и его метаболитов нарушать равновесие в редокс-состоянии органов и крови путем усиления генерирования супероксидных радикалов, которые проявляют как сигнальные, так и повреждающие эффекты. Накопились данные о том, что окислительный метаболизм эстрогена с образованиями катехол-эстроген-3,4-хинонов имеет потенциал инициировать РГЖ. Цель. Исследовать уровень церулоплазмина (ЦП), трансферрина (ТФ), NO-гемоглобина (NO-Hb), метгемоглобина (MetHb), «свободного» железа, супероксид- и NO-генерирующей активности нейтрофилов и матриксных металлопротеиназ- 2 и -9 в крови больных РГЖ ІІ-ІІІ стадии с различным гормонорецепторным статусом опухолей. Объект и методы. Исследована кровь больных РГЖ в репродуктивном и постменопаузальном возрасте. Уровень ЦП, ТФ, «свободного» железа, гемихрома, МetHb, NO-Нb и убисемихинона исследовали методом электронного парамагнитного резонанса (ЭПР) в низкотемпературном режиме (77 К). Скорость генерации супероксидных радикалов нейтрофилами определяли методом ЭПР при комнатной температуре с использованием спиновогоуловителя TEMPONE-H («Sigma»). NO-генерирующую активность нейтрофилов крови определяли методом ЭПР с использованием технологии Spin Traps при температуре 77 К (спиновый уловитель - диэтилдитиокарбамат). Уровень активных форм желатиназы в сыворотке крови определяли методом зимографии в полиакриламидном геле. Результаты. У пациенток репродуктивного и постменопаузального возраста с эстроген-рецептор (ER)

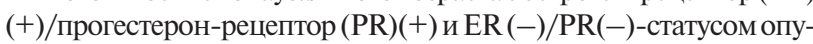
холей уровень ЦП превышал значения, характерные для доноров, а уровень ТФ был достоверно ниже. Содержание в крови NO-Hb было самым высоким у больных РГЖ в постменопаузальном возрасте с $\mathrm{ER}(-) / \mathrm{PR}(-)$-статусом опухолей и прямо коррелировало c NO-генерирующей активностью нейтрофилов $(\mathrm{r}=0,56 ; \mathrm{p}<0,05)$. Активность матриксной металлопротеиназы-9 в сыворотке крови больных с ER(-)/PR(-)-статусом опухолей в 3,3 раза достоверно превышала таковую у больных с $\mathrm{ER}(+) / \mathrm{PR}(+)$. В крови $78 \%$ больных РГЖ постменопаузального возраста с ER(-)/PR(-) выявлено повышение содержания метаболитов эстрогенов - хинонов и убисемихинонов, уровень последних прямо коррелировал со стадией опухолевого процесса $(\mathrm{r}=0,58 ; \mathrm{p}<0,05)$. Установлено, что нейтрофилы в крови больных репродуктивного возраста c ER(+)/PR (+) и ER(-)/PR(-) генерируют супероксидные радикалы со скоростью, которая является соответственно в 9 и 18 раз выше по сравнению с донорами, а NO - более чем в 12 раз независимо от гормонорецепторного статуса опухолей. Вывод. Выявлены нарушения редокс-состояния крови у больных РГЖ, изменения которого зависят от гормонорецепторного статуса опухолей, в частности $\mathrm{ER}(+) / \mathrm{PR}(+)$ и $\mathrm{ER}(-) / \mathrm{PR}(-)$. Характерное для больных РГЖ редокс-состояние крови формируется повышением супероксид- и NO-генерирующей активности нейтрофилов, появлением значительных уровней $\mathrm{NO}-\mathrm{Hb}$, MetHb, гемихрома, убисемихинонов и активности желатиназы. Выявлено влияние определенных показателей на течение заболевания и выживаемость больных РГЖ.

Ключевые слова: рак грудной железы, гормонорецепторный статус, редокс-состояние крови, супероксидные радикалы, оксид азота.
Prognostic value of blood redox-state indicators in patients with breast cancer

A.P. Burlaka', O.I. Sydorchuk', I.M. Motuzyuk ${ }^{2}$, S.V. Virko ${ }^{3}$,

V.A. Chernobai ${ }^{3}$, I.I. Ganusevich ${ }^{1}$

${ }^{1}$ R.E. Kavetsky Institute of Experimental Pathology, Oncology and Radiobiology, NAS of Ukraine, Kyiv

${ }^{2}$ Bogomolets National Medical University, MH of Ukraine, Kyiv ${ }^{3}$ V. E. Lashkaryov Institute of Semiconductor Physics, NAS of Ukraine, Kyiv

Summary. Introduction. In women of postmenopausal age plasma circulating levels of estrogens and their levels in mammalian glands reduced. However, breast cancer rate in this cohort remains to be high meaning the presence of other damaging factors. Capacity of estrogens and their metabolites to change the balance in redox-state of organs and blood though the increase of superoxide radicals generation rate which in turn have signaling and damaging effects is a factor of high importance. Numbers of data show that oxidative metabolism of estrogens leads to catechol estrogen-3,4-quinones formation and this has a great potential in breast cancer initiation. Objective. To investigate the level of ceruloplasmin (CP), transferrin (TF), NO-hemoglobin (NO-Hb), methemoglobin (MetHb), superoxide- and NO-generating activity of neutrophils and matrix metalloproteinases- 2 and -9 in the blood of patients with breast cancer in connection with the hormone receptor status of tumors of patients with breast cancer in II-III stages. Object and methods. Blood samples were studied in patients with breast cancer IIIII stages in reproductive and postmenopausal age. The level of CP, TF, «free» iron, hemichromes, MetHb, NO-Hb, and ubisemiquinone was investigated by the method of electron paramagnetic resonance (EPR) in a low-temperature mode $(77 \mathrm{~K})$. The rate of generation of superoxide radicals by neutrophils was determined by EPR method at room temperature using the spin capture TEMPONE-H («Sigma»). The NO-generating activity of blood neutrophils was determined by the EPR method using Spin Traps technology at a temperature of $77 \mathrm{~K}$ (spin trap - diethyldiothiocarbamate). The level of active forms of gelatinase in serum was determined by zymography in a polyacrylamide gel. Results. In patients with reproductive and postmenopausal age with $\mathrm{ER}(+) / \mathrm{PR}(+)$ and $\mathrm{ER}(-) / \mathrm{PR}(-)$-status, the level of CP exceeded the values characteristic of donors, and the level of TF in them was significantly lower than control. An increase in NO-Hb content in blood was observed, this indicator was highest in postmenopausal patients with $\mathrm{ER}(-) / \mathrm{PR}(-)$-status and directly correlated with NO-generating activity of neutrophils $(r=0.56 ; \mathrm{p}<0.05)$. The activity of matrix metalloproteinase-9 in the serum of patients with $\mathrm{ER}(-) / \mathrm{PR}(-)$-status in 3.3 times significantly exceeded that for patients with $\mathrm{ER}(+) / \mathrm{PR}(+)$-status. In the blood of $78 \%$ of patients with postmenopausal breast cancer with the status of tumors with $\mathrm{ER}(-) / \mathrm{PR}(-)$, increased content of estrogen metabolites - quinones and ubisemiychinones was observed. The level of the latter was directly correlated with the stage of the tumor process $(r=0.58 ; p<0,05)$. It has been established that neutrophils in the blood of patients of reproductive age with $\mathrm{ER}(+) / \mathrm{PR}(+)$ and $\mathrm{ER}(-) / \mathrm{PR}(-)-$ status of tumors generate superoxide radicals with a rate 9 and 18 times higher compared to donors, respectively, and $\mathrm{NO}$ - more than 12 times in both subgroupes. Conclusion. Reactions of the redox state of the blood in patients with breast cancer, whose changes depend on the hormone receptor status of the tumors, in particular $\mathrm{ER}(+) / \mathrm{PR}(+)$ and $\mathrm{ER}(-) / \mathrm{PR}(-)$, are revealed.

Key words: breast cancer, hormone receptor status, blood redoxstate, superoxide radicals, nitric oxide.

Адреса:

Бурлака Анатолій Павлович

03022, Київ, вул. Васильківська, 45

Інститут експериментальної патології, онкології

і радіобіології ім. Р.С. Кавецького НАН України

E-mail: apburlaka@gmail.com

Correspondence: Burlaka Anatoliy

45 Vasylkivska str., Kyiv, 03022

R.E. Kavetsky Institute of Experimental Pathology, Oncology and Radiobiology, NAS of Ukraine E-mail: apburlaka@gmail.com 